\title{
TGF- $\beta$ Isoforms and Receptors: A Gene Expression Analysis in Multiple Sclerosis Patients and Normal Individuals
}

\section{Zeinab Shirvani-Farsani}

Shahid Beheshti University

Mehrdad Behmanesh ( $\nabla$ behmanesh@modares.ac.ir)

Department of Genetics, Faculty of Biological Sciences, Tarbiat Modares University, Tehran, Iran

Mohammad Ali Sahraian

Tehran University of Medical Sciences

\section{Research note}

Keywords: TGF- $\beta$ Pathway, TGF- $\beta$ receptors, Multiple Sclerosis, Expression Analysis, Real-Time PCR

Posted Date: January 19th, 2021

DOI: https://doi.org/10.21203/rs.3.rs-145981/v1

License: (c) (1) This work is licensed under a Creative Commons Attribution 4.0 International License.

Read Full License 


\section{Abstract}

Objective: Multiple sclerosis (MS) is a chronic inflammatory disease of the central nervous system (CNS), depicted by lymphocytic infiltration and demyelination. MS is associated with the up-regulation of proinflammatory and down-regulation of anti-inflammatory cytokines. The purpose of this experimental study was to evaluate the expression level of TGF- $\beta 1$, TGF- $\beta 2$, TGF- $\beta-R 1$ and TGF- $\beta-R 2$ mRNAs in peripheral blood mononuclear cells (PBMCs) from MS patients and healthy controls using Real-Time PCR.

Results: Our findings indicated that the TGF- $\beta-R 1$ expression level was 2.25 times higher in controls than MS patients. Also, a significant correlation between normalized expression of TGF- $\beta$-R1 and TGF- $\beta 1$, or TGF- $\beta 2$ was observed. Therefore, these genes could likely play an important role in the etiology of MS.

\section{Introduction}

Multiple sclerosis (MS) is a chronic inflammatory disease, characterized by lymphocytic infiltration and demyelination in the central nervous system (CNS) [1-3]. Prognosis, diagnose and treatment of this disorder rely upon a greater determination of the mechanisms underlying MS onset and development [4]. Inflammatory cascade and the role of different immune cells (including macrophages, natural killer cells and certain lymphocytes populations) are two considerable factors in the etiology of this disease [5].

In MS dependent inflammatory cascade, various cytokines are up-regulated or down-regulated, including pro-inflammatory (e.g. IFN- $\gamma$, TNF-a and IL-12) and anti-inflammatory (e.g. IL-10) cytokines [6]. TGF- $\beta$, as one of most critical anti-inflammatory factor, is secreted not only by the immune cells (mainly macrophages) but also the other non-hematopoietic cells [7]. The role of transforming growth factor- $\beta$ (TGF- $\beta$ ) has been studied in several disorders, particularly in many autoimmune diseases like MS [8-10].

This cytokine is a protein presented in three isoforms: TGF- $\beta 1$, TGF- $\beta 2$ and TGF- $\beta 3$ [11]. All of the TGF- $\beta$ isoforms could participate in the generation of chronic MS lesion [12]. Mechanistically, TGF- $\beta$ signals are generally initiated through binding this factor to the heterodimer complex, composed of type I and II transmembrane receptor serine/threonine kinase, transforming growth factor- $\beta$ receptor 1 (TGF- $\beta$-R1) and TGF$\beta-R 2$ [13]. Thus far, several functions have been determined for TGF- $\beta$ in MS pathogenesis, including 1) suppressing the immune responses, 2 ) inhibiting $T$ cells, $B$ cells as well as many other cells, 3 ) inducing the production of regulatory T cells (Treg), 4) repressing leukocyte adhesion to endothelium, 5) downregulation of adhesion molecules, and 6 ) sustaining a state of immune tolerance $[14,15]$.

With regards to the importance of TGF- $\beta$ role in MS pathogenesis, in this experiment, we evaluated the gene expression level of two relevant isoforms (TGF- $\beta 1$ and TGF- $\beta 2$ ) as well as receptors (TGF- $\beta$-R1 and $T G F-\beta-R 2$ ) in peripheral blood mononuclear cells (PBMCs) of MS patients, in comparison with normal individuals. In addition, we investigated correlation of the gene expressions with the expanded disability status scale (EDSS), the age of onset or the disease length. 


\section{Methods And Materials}

\section{Patient and control participants}

This experimental study was conducted in the genetics Laboratory of Tarbiat Modares University (Tehran, Iran) within 2013-2014. In this research, 61 MS patients and 36 age-, race-, and sex-matched controls were recruited from Multiple Sclerosis centers at Sina Hospital (Tehran, Iran) to investigate the mRNA expression level of TGF- $\beta 1, T G F-\beta 2, T G F-\beta-R 1$ and TGF- $\beta-R 2$ genes. The patients were diagnosed according to the McDonald criteria. informed consent was obtained from all human adult participants and the study was approved by the Ethics Committee of Tarbiat Modares University (ethical code: d52/6723).

\section{RNA extraction and cDNA synthesis}

After blood collection, PBMC separation was performed using density gradient Ficoll/Paque solution (lympholyte, Cedarlane, Netherlands) and total RNA was extracted from all patient and control samples, using RNXTM-plus reagent (Cinnagen, Iran) according to the manufacturer's protocol. The samples were subsequently reverse-transcribed into cDNA, using $3 \mu \mathrm{g}$ total RNA and $250 \mu \mathrm{g}$ oligo dT (MWG, Germany). The reaction was incubated at $70^{\circ} \mathrm{C}$ for 10 minutes and cooled on ice for 3-5 minutes, followed by adding RNase inhibitor, $10 \mathrm{mM}$ dNTPs and Reverse Transcriptase (all from Fermentas, Canada) to $20 \mathrm{ml}$ total volume of reaction mixture. The mixture was ultimately incubated at $42^{\circ} \mathrm{C}$ and $80^{\circ} \mathrm{C}$ for $60-90$ and 15 minutes, respectively.

\section{Quantitative reverse transcriptase PCR}

CDNA for each sample was used to evaluate the mRNA expression level of TGF- $\beta 1, T G F-\beta 2, T G F-\beta-R 1$ and $T G F-\beta-R 2$ genes using relative quantitative reverse transcriptase PCR (qRT-PCR). In this experiment, glyceraldehyde3-phosphate dehydrogenase $(G A P D H)$ was utilized as housekeeping gene.

Each qRT-PCR reaction was performed in a final volume of $20 \mu \mathrm{l}$, using $10 \mathrm{ng}$ CDNA, 2x SYBR Green I master mix (Takara, Shiga, Japan) and appropriate primer pair set (Table S1). Thermal condition, as onestep RT-PCR, was carried out by an initial step at $95^{\circ} \mathrm{C}$ for 15 minutes, followed by 40 cycles at $95^{\circ} \mathrm{C}, 60^{\circ}$ $\mathrm{C}$ and $72^{\circ} \mathrm{C}$ for 15 seconds, 30 seconds and 30 seconds, respectively, in Applied Biosystems 7500 RealTime PCR System (Applied Biosystems, USA). Termed cycle threshold (Ct) was determined for each sample, and the average $\mathrm{Ct}$ of duplicate samples was calculated.

\section{Statistical analysis}

Relative quantification data analysis was performed using arbitrary method $(\Delta \mathrm{Ct})$. The significance of differences between control and test groups was determined by independent $t$-test using SPSS software (Version 20; SPSS Inc, Chicago, USA) and GraphPad Prism 5 (GraphPad Software, Inc., San Diego, USA). The correlation analysis was assessed by Pearson's correlation coefficient. A P-value of 0.05 was set as significant threshold. 


\section{Results}

In this experiment, the age of MS Patients was between 18 and 52 years, with a female to male ratio of 51:10. The control individuals were between 22-45 years of age, with a female to male ratio of 25:11. The demographic characteristics of patients are given in the Table 1.

\section{Gene expression analyses in MS patients compared to the controls}

Findings showed that the TGF- $\beta-R 1$ mRNA level mean was significantly increased in the PBMCs obtained from the controls compared to MS patients (2.25 times, $p=0.025)$. However, no significant difference was observed for TGF- $\beta 1, T G F-\beta 2$ and TGF- $\beta-R 2$ mRNA expression levels (Fig. 1).

\section{Analysis of the relationship between the expression levels of genes}

We investigated the correlation between mean mRNA levels of the analyzed genes. There was a significant positive association between TGF- $\beta-R 1$ mRNA level mean and TGF- $\beta 1$, or TGF- $\beta 2$ in MS patients, but no significant correlation was observed between the other genes mRNA expression level mean (Table 2).

Moreover, we observed no significant correlation between the normalized expression level of TGF- $\beta 1$, TGF- $\beta 2$ or TGF- $\beta-R 1$ genes and disease length, EDSS scores, or age in MS patients. In contrast, data analysis showed a significant positive correlation between TGF- $\beta-R 2$ mRNA expression level and disease length in the MS patients $(r=0.356, p=0.006)$.

\section{Discussion}

TGF- $\beta$ isoforms (TGF- $\beta 1,-\beta 2$, and $-\beta 3$ ) are signaling ligands that promote expression of the extracellular matrix protein components, control growth and differentiation of the epithelial cells, and regulate immune cell function. Thus, the study of TGF- $\beta$ isoforms and their receptors expression may be useful in determining different responses to the immunomodulatory as well as combinatory therapies. Curiously, TGF- $\beta$ isoforms are important due to their conservation among vertebrates and their different roles in a variety of human diseases including tissue fibrosis, cancer and MS [15]. CNS degeneration and inflammation are important causes of demyelination in MS [16]. In 1998, Vincent et al. compared expression of TGF- $\beta-R 1$ and TGF- $\beta$-R2 by immunohistochemistry in the brain tissue of MS patients and normal controls. They determined that TGF- $\beta$ isoforms were expressed in microglia cells of the normal individuals' brain tissue. They also demonstrated that the TGF- $\beta$ isoforms and relevant receptors are expressed in MS lesions [17].

Expression profiling of the MS patients' peripheral blood showed misregulation of SMAD4, SMAD7 and TGF- $\beta-R 2$. These finding revealed that TGF- $\beta$ regulation is reduced in MS patients [18]. Here, we demonstrated no significant difference in TGF- $\beta 1, T G F-\beta 2$ and TGF- $\beta-R 2$ mRNA expression levels in the 
MS patients compared to controls, while TGF- $\beta-R 1$ expression level was 2.25 times higher in normal subjects compared to the MS patients.

Several investigations have so far represented difference of TGF- $\beta 1$, TGF- $\beta 2$, TGF- $\beta-R 1$ and TGF- $\beta$-R2 mRNA levels in vitro and in vivo. TGF- $\beta$ over-expression in MS patients, with little disability after thymectomy, disclosed that this protein could have a favorable effect on human diseases with autoimmune background [19]. Peress et al. have previously examined glial TGF- $\beta$ expression of different isoforms in $14 \mathrm{MS}$ patients. Active lesions illustrated TGF- $\beta 2$ immuno-reactivity of lesion encircling ramified microglia. In contrary, all three isoforms of this protein were expressed in the astrocytes of active white matter lesions. These results proposed that TGF- $\beta$ cytokines could be locally expressed in demyelinated cells [20].

Further investigations showed that induction of rTGF- $\beta 1$ suppressed IFN- $\gamma$, IL-4, IL-6, TNF- $\alpha$ and perforin up-regulation in MS, but it had no effects on IL-10 or TGF- $\beta$ expression. The selective prohibitory effects of TGF- $\beta 1$ on pro-inflammatory cytokines expression potentially turn it into an attractive treatment in MS disease [21].

MS patients with no or slight disability showed high level of TGF- $\beta$ mRNA expression, while moderate or severe disability of MS patients was correlated with high level of IFN- $\sigma$-positive cells. Therefore, TGF- $\beta$ and IFN- $\sigma$ could have dissenting effects on MS pathology. Thus, administration of IFN- $\sigma$ inhibitors and/or TGF- $\beta$ activators might improve MS disease treatment [22].

These differences between our results and others may be due to environment factors including Vitamin $D$ [23] or other drugs that patients use. We formerly studied TGF- $\beta 1$ expression in 32 patients with MS and 32 healthy controls. Our findings showed no significant change of TGF- $\beta 1$ expression in the MS patients compared to control group [24], suggesting that large sample size could not affect gene regulation level.

Additionally, this study evaluated the correlation between these four gene expressions in MS patients. We detected a positive link only between the expression of $T G F-\beta 1$ and TGF- $\beta-R 2$ as well as the expression of $T G F-\beta 2$ and TGF- $\beta-R 1$ in MS patients; however, there was no significant association between the expressions of other genes. It is proposed that TGF- $\beta$-R1 might influence on TGF- $\beta 1$ and TGF- $\beta 2$ expression by phosphorylating the receptor-specific SMADs and promoting a feedback mechanism. Altogether, expression level of TGF- $\beta$-R1 could be considered as a risk factor for MS disease which might be associated with inflammatory events in such patients.

\section{Limitations}

Investigations have previously implicated that heterogeneous nature of whole-blood samples may not show the optimal level of gene expressions [25, 26], revealing some limitation in this study. Hence, assessment of gene expression at protein level MS patients' sorted PBMCs could help to better understand the role of TGF- $\beta$. 


\section{Abbreviations}

MS: Multiple sclerosis

CNS: central nervous system

PBMCs: peripheral blood mononuclear cells

EDSS: expanded disability status scale

TGF- $\beta$ : transforming growth factor- $\beta$

TGF- $\beta-R 1$ : transforming growth factor- $\beta$ receptor 1

\section{Declarations}

\section{Ethics approval and consent to participate}

This study was in accordance with the declaration of Helsinki. This study was approved by the Ethics Committee of Tarbiat Modares University. The informed consent was obtained from all the participants, and informed consent obtained was written.

\section{Consent for publication}

Not applicable.

\section{Availability of data and materials}

All relevant data are included in the manuscript.

\section{Competing interests}

The authors declare that they have no competing interests.

\section{Funding}

This research did not receive any specific grant from funding agencies in the public, commercial, or notfor-profit sectors.

\section{Authors' Contributions}

Z.SHF., M.B.; Performed all experiments, analyzed the data and wrote the manuscript. M.A.S.; Contributed to concept and design, manufactured the samples, and final approval of the manuscript. All authors read and approved the final manuscript.

\section{Acknowledgements}


The authors gratefully acknowledge contribution of the patients and institutions in this study as well as Roya Amirinejad and Fahimeh Molaahmadi for their valuable laboratory supports. This research received no specific grant from any funding agency in the public, commercial, or not-for-profit sectors, other than Department of Research Affairs of Tarbiat Modares University.

\section{References}

1. Bhise $V$, Dhib-Jalbut $S$ : Further understanding of the immunopathology of multiple sclerosis: impact on future treatments. Expert review of clinical immunology 2016, 12(10):1069-1089.

2. Touil H, Kobert A, Lebeurrier N, Rieger A, Saikali P, Lambert C, Fawaz L, Moore CS, Prat A, Gommerman $\mathrm{J}$ et al: Human central nervous system astrocytes support survival and activation of $\mathrm{B}$ cells: implications for MS pathogenesis. Journal of neuroinflammation 2018, 15(1):114.

3. Tian Z, Song Y, Yao Y, Guo J, Gong Z, Wang Z: Genetic Etiology Shared by Multiple Sclerosis and Ischemic Stroke. Frontiers in genetics 2020, 11:646.

4. Baecher-Allan C, Kaskow BJ, Weiner HL: Multiple Sclerosis: Mechanisms and Immunotherapy. Neuron 2018, 97(4):742-768.

5. Pérez-Cerdá F, Sánchez-Gómez MV, Matute C: The link of inflammation and neurodegeneration in progressive multiple sclerosis. Multiple Sclerosis and Demyelinating Disorders 2016, 1(1):9.

6. Nali LH, Olival GS, Sousa FTG, de Oliveira ACS, Montenegro H, da Silva IT, Dias-Neto E, Naya H, Spangenberg L, Penalva-de-Oliveira AC et al: Whole transcriptome analysis of multiple Sclerosis patients reveals active inflammatory profile in relapsing patients and downregulation of neurological repair pathways in secondary progressive cases. Multiple Sclerosis and Related Disorders 2020, 44:102243.

7. Komai T, Inoue M, Okamura T, Morita K, Iwasaki Y, Sumitomo S, Shoda H, Yamamoto K, Fujio K: Transforming Growth Factor- $\beta$ and Interleukin-10 Synergistically Regulate Humoral Immunity via Modulating Metabolic Signals. Frontiers in Immunology 2018, 9(1364).

8. Sanjabi S, Oh SA, Li MO: Regulation of the Immune Response by TGF- $\beta$ : From Conception to Autoimmunity and Infection. Cold Spring Harbor Perspectives in Biology 2017, 9(6).

9. Lee PW, Severin ME, Lovett-Racke AE: TGF- $\beta$ regulation of encephalitogenic and regulatory T cells in multiple sclerosis. European Journal of Immunology 2017, 47(3):446-453.

10. Kashima R, Hata A: The role of TGF- $\beta$ superfamily signaling in neurological disorders. Acta Biochimica et Biophysica Sinica 2017, 50(1):106-120.

11. Voisin A, Damon-Soubeyrand C, Bravard S, Saez F, Drevet JR, Guiton R: Differential expression and localisation of TGF- $\beta$ isoforms and receptors in the murine epididymis. Scientific reports 2020 , 10(1):995.

12. Compston A, Lassmann $\mathrm{H}$, Smith $\mathrm{K}$ : Chapter 10 - The neurobiology of multiple sclerosis. In: McAlpine's Multiple Sclerosis (Fourth Edition). Edited by Wekerle ACCLMMNS. Edinburgh: Churchill Livingstone; 2006: 449-490. 
13. Hata A, Chen Y-G: TGF- $\beta$ Signaling from Receptors to Smads. Cold Spring Harbor Perspectives in Biology 2016, 8(9).

14. Xu J, Wang Y, Jiang H, Sun M, Gao J, Xie A: TGF- $\beta$ in Mice Ameliorates Experimental Autoimmune Encephalomyelitis in Regulating NK Cell Activity. Cell transplantation 2019, 28(9-10):1155-1160.

15. Nataf S, Guillen M, Pays L: TGFB1-Mediated Gliosis in Multiple Sclerosis Spinal Cords Is Favored by the Regionalized Expression of HOXA5 and the Age-Dependent Decline in Androgen Receptor Ligands. Int J Mol Sci 2019, 20(23).

16. Zhang $\mathrm{X}$, Hamblin $\mathrm{MH}$, Yin $\mathrm{KJ}$ : The long noncoding RNA Malat1: Its physiological and pathophysiological functions. RNA biology 2017, 14(12):1705-1714.

17. Vincent $V$, Tilders F, Van Dam A: Production, regulation and role of nitric oxide in glial cells. Mediators of inflammation 1998, 7(4):239.

18. Meoli EM, Oh U, Grant CW, Jacobson S: TGF- $\beta$ signaling is altered in the peripheral blood of subjects with multiple sclerosis. Journal of neuroimmunology 2011, 230(1):164-168.

19. Ateke Mousavi N-k, Abbas M, Abdorreza Naser M, Mohammad Reza S-S, Mohammad Reza E, Maryam S, Mina A, Ali Akbar S-Y: Comparison of Cytokine Expression in Multiple Sclerosis Patients and Healthy Volunteers. Acta Medica Iranica 2018, 56(2).

20. Peress NS, Perillo E, Seidman RJ: Glial transforming growth factor (TGF)- $\beta$ isotypes in multiple sclerosis: differential glial expression of TGF- $\beta 1,2$ and 3 isotypes in multiple sclerosis. Journal of neuroimmunology 1996, 71(1):115-123.

21. Araujo GR, Aglas L, Vaz ER, Machado Y, Huber S, Himly M, Duschl A, Goulart LR, Ferreira F: TGFß1 mimetic peptide modulates immune response to grass pollen allergens in mice. Allergy 2020 , 75(4):882-891.

22. Link J, Söderström M, Olsson T, Höjeberg B, Ljungdahl $\AA$, Link H: Increased transforming growth factor- $\beta$, interleukin-4, and interferon- $\gamma$ in multiple sclerosis. Annals of neurology 1994, 36(3):379386.

23. Shirvani-Farsani Z, Behmanesh M, Mohammadi SM, Naser Moghadasi A: Vitamin D levels in multiple sclerosis patients: Association with TGF- $\beta 2$, TGF- $\beta R$ I, and TGF- $\beta R$ Il expression. Life Sciences 2015, 134:63-67.

24. Shirvani-Farsani Z, Behmanesh M, Sahraian MA: Interleukin-10 but not transforming growth factor$\beta 1$ gene expression is up-regulated by vitamin $D$ treatment in multiple sclerosis patients. Journal of the Neurological Sciences 2015, 350(1):18-23.

25. Pahlevan Kakhki M, Rakhshi N, Heidary M, Behmanesh M, Nikravesh A: Expression of suppressor of cytokine signaling 1 (SOCS1) gene dramatically increases in relapsing-remitting multiple sclerosis. $J$ Neurol Sci 2015, 350(1-2):40-45.

26. Heidary M, Rakhshi N, Pahlevan Kakhki M, Behmanesh M, Sanati MH, Sanadgol N, Kamaladini H, Nikravesh A: The analysis of correlation between IL-1B gene expression and genotyping in multiple sclerosis patients. J Neurol Sci 2014, 343(1-2):41-45. 


\section{Tables}

Table 1 Demographic and disease characteristics of the MS patients and controls.

\begin{tabular}{|lll|}
\hline & MS Patient & Control \\
\hline Number & 61 & 31 \\
\hline Age (mean years \pm SD) & $32.54 \pm 8.45$ & $29.03 \pm 6.81$ \\
\hline RR/SP/PP & $55 / 6 / 0$ & - \\
\hline EDSS (mean \pm SD) & $2.45 \pm 1.33$ & - \\
\hline Disease Duration & $6.42 \pm 3.72$ & - \\
\hline
\end{tabular}

Table 2 Correlation between normalized TGF- $\beta 1, T G F-\beta 2, T G F-\beta-R 1$ or TGF- $\beta-R 2$ expression level in MS patients.

\begin{tabular}{|lll|}
\hline correlation & $\mathrm{r}$ & $\mathrm{p}$-value \\
\hline TGF- $\beta 1$ 1-TGF- $\beta 2$ & 0.077 & 0.551 \\
\hline TGF- $\beta 1$ 1-TGF- $\beta$ RI & $\mathbf{0 . 2 9 2}$ & $\mathbf{0 . 0 2 3 ^ { * }}$ \\
\hline TGF- $\beta 1-T G F-\beta$ RII & 0.164 & 0.216 \\
\hline TGF- $\beta 2-T G F-\beta$ RI & $\mathbf{0 . 4 7 7}$ & $\mathbf{0 . 0 0 0 1 ^ { * * * }}$ \\
\hline TGF- $\beta 2-T G F-\beta$ RII & 0.010 & 0.9939 \\
\hline TGF- $\beta$ RI-TGF- $\beta$ RII & 0.194 & 0.143 \\
\hline
\end{tabular}

*significant $p$-value $<0.05$

***significant $p$-value $<0.001$

\section{Figures}




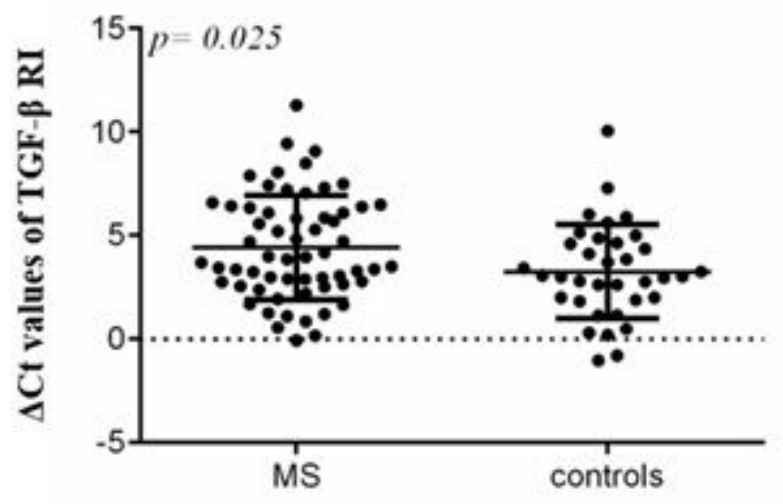

A

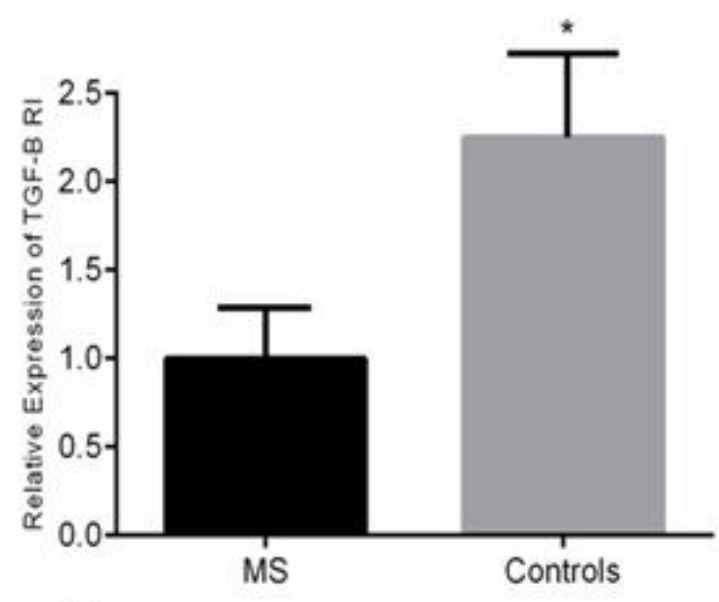

B

\section{Figure 1}

TGF- $\beta-R 1$ gene expression in PBMCs. A) The mRNA expression of this gene shows significant increase in the controls compared to MS patients (2.25 times). B) $\Delta$ Ct values in the patient and control samples. The results were normalized relative to the level of GAPDH mRNA expression.

\section{Supplementary Files}

This is a list of supplementary files associated with this preprint. Click to download.

- Tables1.docx 